\title{
SOSIALISASI MEDIA PEMBELAJARAN DAN PROGRAM STATISTIKA DI SD NEGERI SETU O1 CIPAYUNG
}

\author{
Ek Ajeng Rahmi Pinahayu' ${ }^{1),}$ Iim Marfu'ah ${ }^{2)}$ \\ ${ }^{1 ’ 2}$ Program Studi Teknik Informatika, FTIK, Universitas Indraprasta PGRI
}

\begin{abstract}
Abstrak
Proses belajar mengajar pada hakikatnya adalah proses komunikasi, yaitu proses penyampaian pesan dari sumber pesan melalui saluran/media tertentu ke penerima pesan. Pada kegiatan belajar mengajar, media merupakan salah satu faktor yang menentukan keberhasilan proses pembelajaran. Media pengajaran seperti permainan ular tangga, permainan kartu domino, dan permainan monopoli dapat mempertinggi proses belajar siswa dalam pengajaran yang pada gilirannya diharapkan dapat mempertinggi hasil belajar dicapainya. Dalam PTK (Penelitian Tindakan Kelas) yang dilakukan oleh guru, guru dapat mengembangkan dalam hal penggunaan dan pemanfaatan media pembelajaran untuk meningkatkan kualitas pembelajaran di kelas. Pelatihan pemanfaatan media pembelajaran dan pelatihan program statistik pengolahan data penelitian untuk mengembangkan kualitas PTK yang dilakukan oleh guru-guru di sekolah bermanfaat untuk meningkatkan keterampilan guru-guru SD dalam menggunakan software SPSS dalam mengolah data Penelitian Tindakan Kelas (PTK).
\end{abstract}

Keywords: Media Pembelajaran, Penelitian Tindakan Kelas, MS Excel, Program SPSS

\begin{abstract}
The teaching and learning process is essentially a communication process, which is the process of delivering messages from the message source through certain channels / media to the recipient of the message. In teaching and learning activities, the media is one of the factors that determine the success of the learning process. Teaching media such as snakes and ladders, domino cards and monopoly games can enhance the learning process of students in teaching, which in turn is expected to enhance the learning outcomes achieved. In PTK (Classroom Action Research) conducted by teachers, teachers can develop in terms of the use and use of learning media to improve the quality of learning in the classroom. Training in the use of instructional media and training in research data processing statistics programs to develop the quality of CAR carried out by teachers in schools is useful for improving the skills of elementary school teachers in using software SPSS in processing Classroom Action Research (PTK) data.
\end{abstract}

Keywords: Learning Media, Classrom Action Research, MS Excel ,SPSS

Correspondence author: Ek Ajeng Rahmi Pinahayu, ekajeng_rahmipinahayu@yahoo.com, Jakarta, Indonesia

This work is licensed under a $C C-B Y-N C$ 


\section{PENDAHULUAN}

Permenegpan \& RB Nomor 16 tahun 2009, tentang Jabatan fungsional Guru dan Angka Kreditnya, guru wajib dinilai kinerjanya dan melaksanakan kegiatan Pengembangan Keprofesian Berkelanjutan (PKB). Salah satu aktivitas PKB yang bisa dicoba guru merupakan melaksanakan penelitian. Untuk mewujudkan hal tersebut guru harus mempunyai kemampuan meneliti, khususnya Penelitian Tindakan Kelas (PTK) (Kelas, Widyaiswara, Yogyakarta, \& Guru, n.d.). Penelitian tindakan merupakan suatu metode penelitian yang berorientasi pada pengembangan atau penyempurnaan suatu ilmu dalam mengatasi suatu permasalahan secara langsung melalui suatu tindakan dan refleksi diri yang didasarkan pada hasil kajian. Oleh karenanya, prosedur dalam penelitian ini menggunakan model siklus, sebagaimana yang dikemukakan oleh Lewins dan Mc Niff menggambarkan action resreach as a spiral of step had four stages: planniang, acting, observing, and reflecting (Zetty Azizatun Ni'mah, 2017). Komponen karya pengembangan profesi melalui PTK para guru dinilai rendah, khususnya penelitian di bidang pendidikan yakni Penelitian Tindakan Kelas (PTK) (Suratmi, Purwaningsih, Sartika, \& Suryani, 2018). Di sisi lain, banyak pemasalahan yang ditemui di dalam kelas, di antaranya atmosfer pendidikan kurang kondusif, siswa kurang bersemangat, kurang mencermati pembelajaran, tidak terampil, kegiatan siswa untuk mengikuti pelajaran cukup rendah, yang aktif hanya dimonopoli oleh siswa tertentu saja, siswa ramai ataupun bermain sendiri, mengantuk, tidak semangat serta cenderung bersikap ke arah negatif, proses pembelajaran kurang interaktif, siswa kurang bisa menguasai konsep dengan benar sehingga hasil belajar siswa kurang sesuai dengan apa yang diharapkan ataupun di bawah Kriteria Ketentuan Minimal (KKM) (Mulia \& Suwarno, 2016).

Dalam PTK yang dilakukan oleh guru, guru dapat mengembangkan dalam hal penggunaan dan pemanfaatan media pembelajaran untuk meningkatkan kualitas pembelajaran di kelas. Kemampuan guru dalam menggunakan Teknologi Informasi akan sangat berdampak terhadap pengembangan bahan ajar yang ada di sekolah tersebut (Pinahayu, Auliya, Widya, \& Adnyani, 2018). Selanjutnya, Noehi Nasution (2004: 7) (dalam Adam, 2015) menuliskan media pendidikan menurut (1) Gagne, media pendidikan sebagai komponen sumber belajar di area siswa yang bisa memicu siswa untuk belajar, (2) Briggs, media pendidikan adalah wahana fisik yang memiliki materi pelajaran serta (3) Wilbur Schramm, media pendidikan adalah teknik pembawa informasi atau pesan pendidikan. Terdapat beberapa alasan, kenapa media pengajaran bisa mempertinggi proses belajar siswa, di antaranya: (1) Pengajaran hendaknya lebih menarik atensi siswa sehingga bisa meningkatkan motivasi belajar, (2) Bahan pengajaran akan lebih jelas maknanya sehingga bisa lebih dimengerti oleh para siswa serta membolehkan siswa menguasai tujuan pengajaran yang lebih baik, (3) Tata cara mengajar akan lebih bermacam-macam, tidak semata-mata komunikasi verbal melalui penuturan perkata oleh guru, sehingga siswa tidak bosan serta guru tidak kehilangan tenaga, terlebih apalagi guru mengajar untuk tiap jam pelajaran, (4) Siswa lebih banyak melakukan kegiatan belajar, karena tidak hanya mencermati penjelasan guru, namun juga kegiatan lain seperti mengamati, mendemonstrasikan serta lain-lain.

Kenyataan di lapangan berkaitan dengan PTK yang seharusnya dilakukan guru sebagai kebutuhan (kalau bukan kebiasaan), ternyata tidak seideal apa yang diharapkan. Banyak guru yang mengeluhkan adanya penelitian sebagai persyaratan untuk memperoleh pengakuan (dan tunjangan) atas profesinya, juga sebagai anak tangga yang 
wajib dilalui untuk memperoleh pangkat yang lebih besar (Pramswari, 2016). Setelah tim pengabdian masyarakat melakukan observasi dan wawancara di SD Negeri Setu 01 Pagi Kelurahan Setu Kecamatan Cipayung Jakarta Timur, diketahui bahwa guru-guru pada SD tersebut masih belum memaksimalkan media pembelajaran dan masih kesulitan dalam pelaksanaan PTK terutama dalam hal pengolahan data penelitian yang diperoleh. Beberapa permasalahan yang dihadapi oleh mitra, di antaranya: (1) Guru masih kesulitan dalam mengembangkan dan memanfaatkan media pembelajaran dalam kegiatan belajar mengajar di dalam kelas, (2) Guru masih kesulitan dalam membuat pembelajaran di dalam kelas yang lebih menarik dan mudah dipahami oleh siswa, (3) Kurangnya media pembelajaran yang dimiliki guru maupun sekolah untuk pengembangan pembelajaran di sekolah, (4) Guru masih kesulitan dalam mengembangkan Penelitian Tindakan Kelas (PTK) terutama dalam hal pengolahan data, dan (5) Guru masih kesulitan dalam menggunakan program statistik untuk analisa data dalam Penelitian Tindakan Kelas (PTK).

Dari latar belakang tersebut maka tim pelaksana pengabdian masyarakat memberi alternatif penyelesaian dengan memberikan bantuan dalam bentuk sosialisasi dan pelatihan pemanfaatan media pembelajaran seperti permainan ular tangga, permainan kartu domino, dan permainan monopoli, serta pelatihan program statistik pengolahan data penelitian untuk mengembangkan kualitas PTK yang dilakukan oleh guru-guru di sekolah tersebut. Hal tersebut bermanfaat untuk meningkatkan keterampilan guru-guru SD dalam menggunakan software Ms. Excel dan SPSS dalam mengolah data Penelitian Tindakan Kelas. Selain itu, dapat meningkatkan ketrampilan guru-guru SD dalam menganalisis secara statistik data Penelitian Tindakan Kelas beserta (PTK) interpretasinya.

\section{METODE PELAKSANAAN}

Kegiatan Pengabdian kepada Masyarakat ini dilaksanakan di SD Negeri Setu 01 Pagi Kelurahan Setu Kecamatan Cipayung Jakarta Timur, pada bulan Desember 2019. Metode yang dilakukan dalam kegiatan pengabdian kepada masyarakat ini adalah melalui beberapa tahap dimulai dari observasi langsung dan wawancara. Pada saat observasi langsung dan wawancara, tim pelaksana langsung datang ke lokasi mitra dan bertemu dengan kepala sekolah, untuk mengetahui kondisi pembelajaran di kelas serta kesulitan-kesulitan yang dihadapi guru guna meningkatkan kualitas pendidikan di sekolah dan penelitian yang dilakukan oleh guru. Kemudian menawarkan solusi untuk memecahkan masalah yang ada. Selanjutnya, sosialisasi dan pelatihan diberikan kepada guru-guru di sekolah dengan jadwal yang telah disepakati, dengan cara presentasi dan demonstrasi yang dilakukan oleh nara sumber. Guru menggunakan perangkat komputer atau Laptop yang ada saat pelatihan dilaksanakan. Pada saat pelatihan, disertai sesi tanya jawab sehingga guru lebih mudah memahami materi yang diberikan. Setelah presentasi dan tanya jawab dilakukan, kemudian dilakukan simulasi. Selanjutnya adalah evaluasi kegiatan yang dilakukan untuk mengetahui pemahaman guru dalam penggunaan teknologi, sehingga hasil dari pelaksanaan pengabdian kepada masyarakat lebih optimal. Bila masih ada kendala yang dialami oleh guru, maka tim pelaksana menjelaskan kembali kepada guru.

Terkait kegiatan pengabdian masyarakat yang akan dilakukan oleh tim pelaksana, mitra menyambut baik dan mengapresiasi sangat positif dengan adanya kegiatan 
tersebut. Beberapa bentuk dukungan yang diberikan oleh mitra antara lain: (1) menyiapkan jadwal dan tempat pelaksanaan kegiatan pengabdian kepada masyarakat, (2) memberikan bantuan kepada tim pelaksana berupa sarana dan prasarana dalam kegiatan yang akan dilaksanakan, (3) mendata guru-guru yang akan mengikuti kegiatan pengabdian kepada masyarakat, (4) menginformasikan jadwal dan tempat kegiatan kepada guru-guru yang akan mengikuti kegiatan pengabdian masyarakat.

\section{HASIL DAN PEMBAHASAN}

Solusi oleh tim pelaksana dalam melakukan pengabdian masyarakat ini adalah dengan memberikan sosialisasi dan pelatihan pembuatan dan pemanfaatan media pembelajaran yang mendukung kegiatan belajar mengajar di dalam kelas, serta pelatihan dalam penggunaan program statistik untuk menghitung dan menganalisis data penelitian yang diperoleh. Adanya pelatihan yang diberikan diharapkan dapat meningkatkan kemampuan guru dalam mengembangkan PTK (Penelitian Tindakan Kelas). Adapun prosedur yang dilakukan tim pelaksana dalam melakukan pelatihan bagi guru ialah: 1) Tim pelaksana menyiapkan materi dan program untuk kegiatan pelatihan dan sosialisasi. 2) Tim pelaksana menyiapkan desain pelatihan bagi guru. 3) Tim pelaksana menyiapkan sarana dan prasarana untuk kegiatan pengabdian kepada masyarakat, yang dibantu langsung oleh pihak sekolah. 4) Tim pelaksana melakukan evaluasi dan analisis hasil kegiatan pengabdian kepada masyarakat.

\section{Media Pembelajaran yang Mendukung PTK}

Adapun cakupan permainan yang dapat dikombinasi dengan materi pelajaran di antaranya permainan ular tangga, permainan kartu domino dan permainan monopoli. Permainan ular tangga tapat dimodifikasi menjadi alat pembelajaran yang sangat menarik perhatian siswa. Media permainan ular tangga bertujuan agar dapat meningkatkan keaktifan siswa, semangat dalam belajar, dan memiliki keberanian dalam mengemukakan pendapat yang akan berdampak pada meningkatnya hasil belajar siswa, serta dapat mempermudah guru untuk menyampaikan materi pembelajaran. Efektivitas media pembelajaran permainan ular tangga telah terbukti melalui sejumlah penelitian, salah satu diantaranya adalah penelitian Afandi (2015) yang menyatakan bahwa media pembelajaran permainan ular tangga mampu meningkatkan motivasi dan hasil belajar IPS siswa SD (Permatasari, n.d.). Untuk mengkombinasikan ular tangga dengan materi pelajaran harus dibuat dengan ketelitian dan kejelian jika tidak permainan ular tangga tidak bisa berfungsi dengan baik.

Definisi domino matematika menurut Sundayana ialah suatu kartu matematika yang didesain menyerupai kartu domino. Kartu domino matematika berisi bermacam pasangan soal serta jawaban, permainan ini bisa dimainkan oleh 2-4 orang. Materi soal yang digunakan pun dapat disesuaikan dengan materi yang diajarkan (Sidarta \& Yunianta, 2019). Untuk permainan kartu domino yang digunakan adalah kartu yang berjumlah 28 kartu yang berisi 7 jenis pertanyaan. Contoh yang mudah pada matematika dapat digunakan pada penjumlahan, pengurangan maupun perkalian dan perkalian.Permainan monopoli juga dapat dikombinasikan dengan materi-pelajaran di sekolah. Sebagai contoh adalah permainan monopoli pada materi perkalian dan pembagian.Berdasarkan penelitian permainan monopoli sebagai media pembelajaran sub materi sel pada siswa IPA yang dilakukan oleh Susanto, dkk. (2012) aspek 
kelayakan 90\%, aspek visual 94\%, aspek fungsi media 92,86\%. Berdasarkan penelitian tersebut makan media permainan monopoli layak digunakan sebagai media pembelajaran.(Belajar, Boga, \& Sma, 2013). Berikut merupakan contoh media pembelajaran yang dapat dibuat untuk mengembangkan PTK oleh guru:
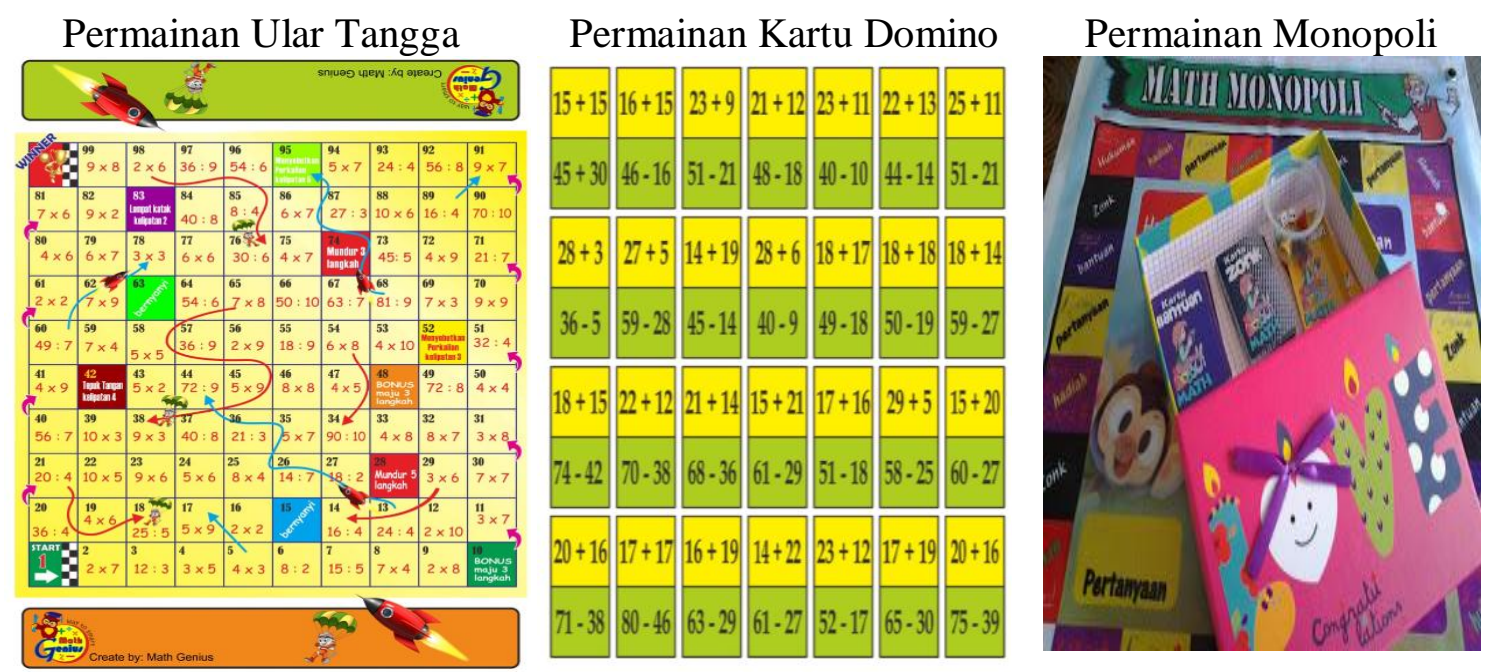

Gambar 1 Contoh Media Pembelajaran Permainan Ular Tangga, Permainan Kartu Domino dan Permainan Monopoli

\section{Program Statistik untuk Mengolah data PTK}

Untuk Program Statistik pengolah data penelitian, tim pengabdian masyarakat memberikan sosialisasi dan pelatihan penggunaan Program SPSS. Kepanjangan Istilah SPSS adalah Statistical Product and Service Solutions. Guru di Negeri Setu 01 Pagi masih awam dengan program SPSS yang diberikan, bahkan banyak yang belum pernah mendengar program tersebut. SPSS dapat digunakan sebagai program untuk mengolah data penelitian, sehingga memudahkan guru dalam mengolah dan menganalisis data penelitian. Jika biasanya guru mengolah data menggunakan dengan menginput manual dan mengetik rumus secara manual di Ms. Excel, maka dengan menggunakan SPSS guru hanya menginput data penelitian dan memilih statistik uji yang akan digunakan, yang selanjutkan Output penelitian dapat langsung dianalisis oleh guru. Jadi dengan penggunaan SPSS dapat membuat Penelitian Tindakan Kelas (PTK) yang dilakukan oleh guru dapat berjalan lebih efektif dan efisien, bahkan hasil perhitungannya pun lebih akurat. Berikut merupakan contoh tampilan dari Program SPSS:

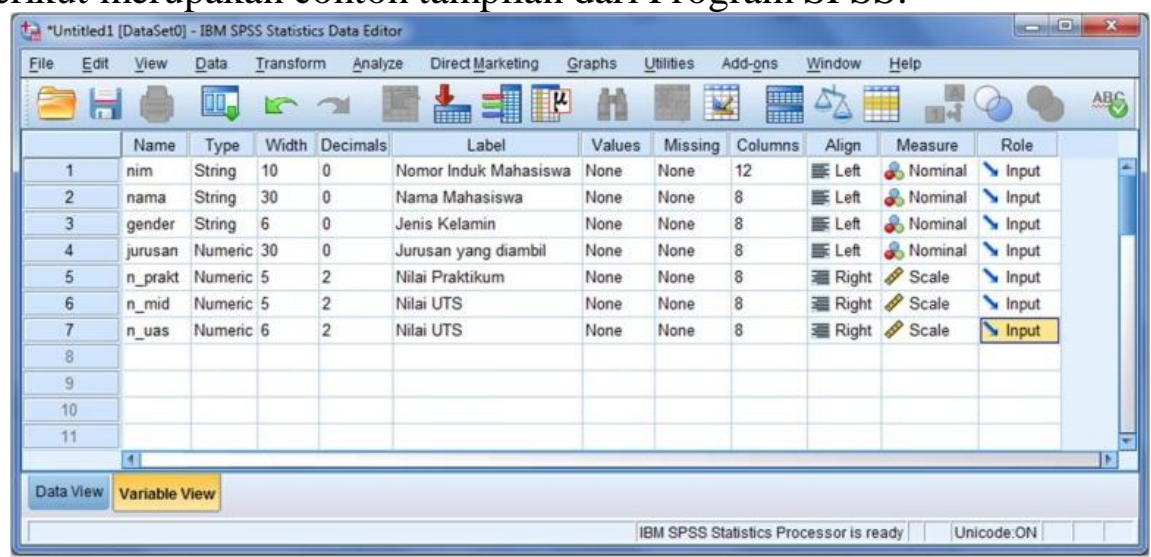

Gambar 2 Tampilan Program SPSS 
Adapun beberapa manfaat yang diperoleh dari kegiatan pengabdian masyarakat ini di antaranya: 1) Guru mendapatkan gambaran mengenai pemanfaaatan media pembelajaran untuk mengembangkan pembelajaran di kelas. 2) Memunculkan ide dari para guru untuk membuat dan mengembangkan media pembelajaran inovatif lainnya yang lebih menarik dan mudah dipahami oleh siswa. 3) Guru menjadi lebih kreatif dalam pengembangan pembelajaran, sehingga dapat meningkatkan pembelajaran dan kualitas PTK di lingkungan sekolah. 4) Dengan belajar SPSS, guru lebih mudah dalam hal pengolahan data dan menganalisis data hasil Penelitian Tindakan Kelas (PTK). 5) Setelah mempelajari SPSS, guru tidak mengalami kendala dalam hal pengolahan data penelitian, sehingga guru semakin bersemangat untuk melakukan Penelitian Tindakan Kelas (PTK). Berikut merupakan dokumentasi dari pelaksanaan kegiatan pengabdian kepada masyarakat yang telah dilakukan di SD Negeri Setu 01 Pagi:

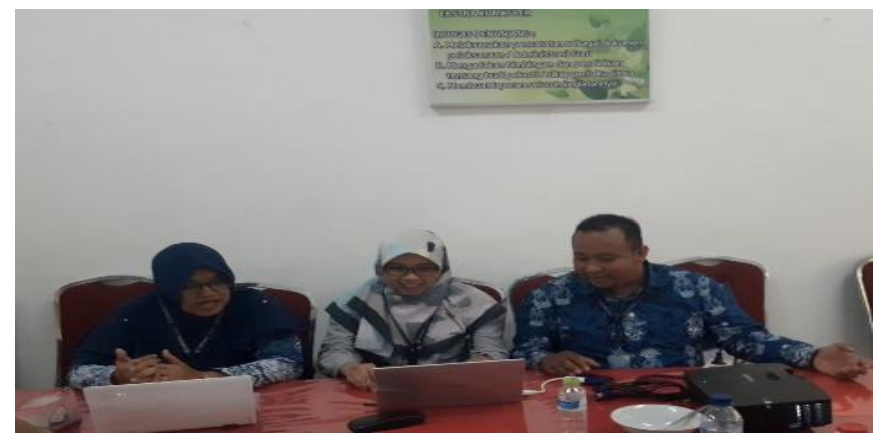

Gambar 3 Pembukaan kegiatan PKM di SD Negeri Setu 01 Pagi

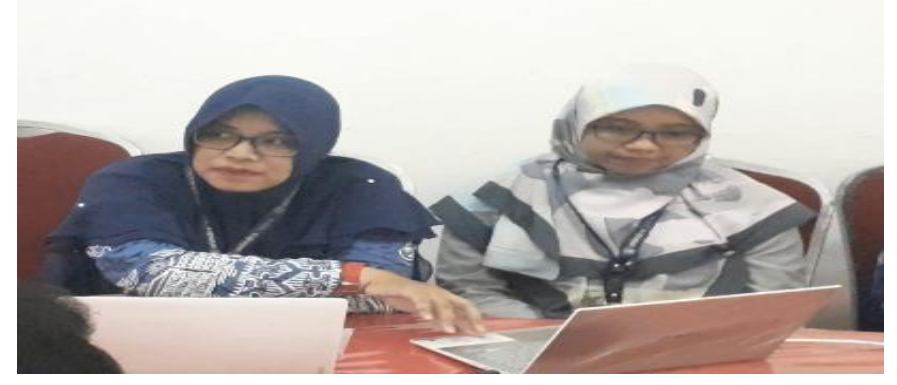

Gambar 4 Tim PKM menjelaskan mengenai Media Pembelajaran

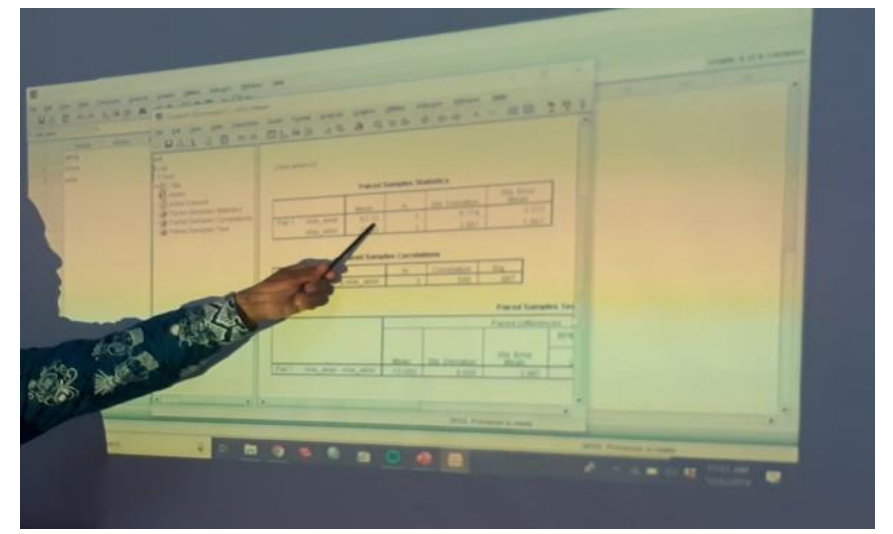

Gambar 5 Tim PKM menjelaskan mengenai penggunaan SPSS 


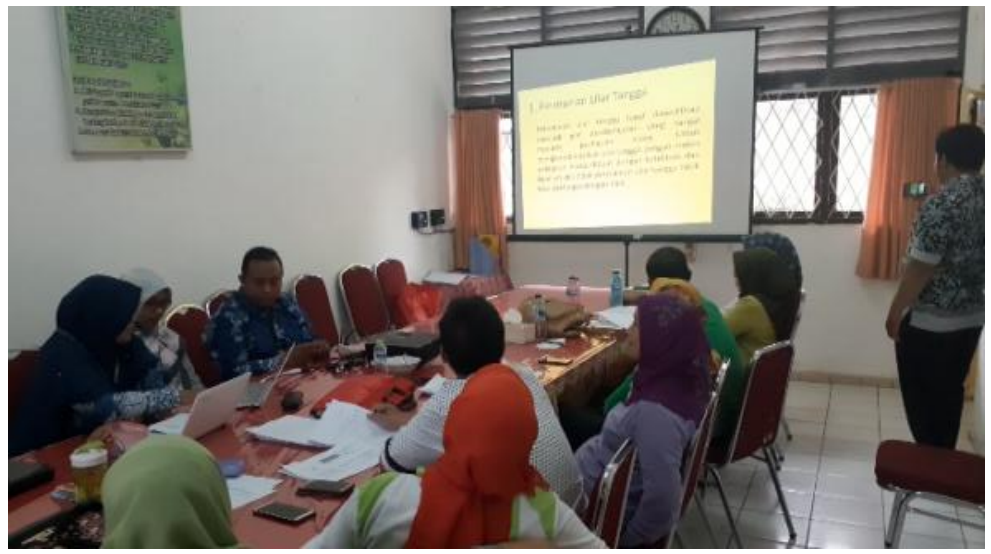

Gambar 6 Sesi Tanya Jawab saat kegiatan PKM

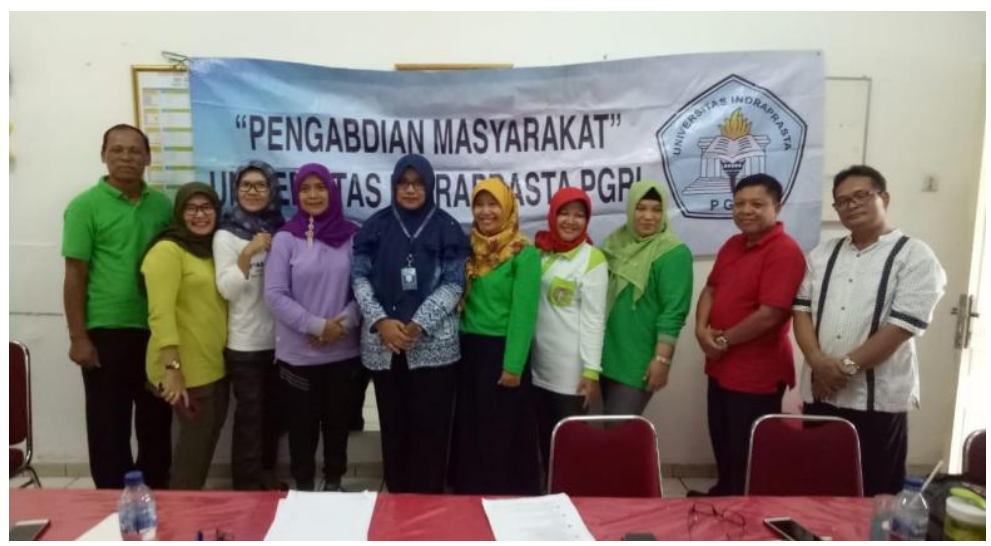

Gambar 7 Sesi Foto bersama dengan peserta kegiatan PKM di SD Negeri Setu 01 Pagi

\section{SIMPULAN}

Simpulan yang didapat dari kegiatan Pengabdian Kepada Masyarakat yang telah dilaksanakan di antaranya: (1) Guru mendapatkan gambaran mengenai pemanfaatan media pembelajaran untuk mengembangkan pembelajaran di kelas, sehingga memudahkan dalam menyampaikan materi kepada siswa. (2) Muncul ide-ide baru dan motivasi dari para guru untuk membuat dan mengembangkan media pembelajaran inovatif lainnya yang lebih menarik dan mudah dipahami oleh siswa. (3) Guru dapat lebih kreatif dalam pengembangan pembelajaran, sehingga dapat meningkatkan pembelajaran dan kualitas PTK di lingkungan sekolah. (4) Guru dapat memanfaatkan perkembangan teknologi informasi dan komunikasi, salah satunya guru mampu menggunakan program statistik SPSS untuk mengolah data hasil Penelitian Tindakan Kelas (PTK) yang dilakukan. (5) Guru lebih memahami Statistika Uji yang digunakan dalam penelitian. (6) Dengan menggunakan SPSS, guru dapat melihat Output hasil penelitian dan dapat langsung menganalisisnya dengan mudah. Setelah dilakukan kegiatan pengabdian masyarakat, mitra berharap untuk diadakan kembali kegiatan serupa di semester berikutnya. Guru-guru juga antusias dan menyambut baik kegiatan Pengabdian kepada Masyarakat yang dilaksanakan. 


\section{DAFTAR PUSTAKA}

Adam, steffi dan M. T (2015). Pemanfaatan Media Pembelajaran Berbasis Teknologi Informasi bagi Siswa Kelas X SMA Ananda Batam. CBIS Journal, 3 No 2(ISSN 2337-8794), 78-90.

Belajar, M., Boga, T., \& Sma, D. I. (2013). Permainan Monopoli sebagai Media untuk Meningkatkan Minat Belajar Tata Boga di Sma. Jurnal Ilmiah Guru Caraka Olah Pikir Edukatif, (1).

Kelas, P. T., Widyaiswara, P., Yogyakarta, L. D. I., \& Guru, A. (n.d.). No Title, 1-15.

Mulia, D. S., \& Suwarno. (2016). PTK (Penelitian Tindakan Kelas) dengan Pembelajaran Berbasis Kearifan Lokal dan Penulisan Artikel Ilmiah di SD Negeri Kalisube, Banyumas. Khazanah Pendidikan Jurnal Ilmiah Kependidikan, Vol. IX, No. 2 (Maret 2016) PTK, IX(2), 11.

Permatasari, M. A. (n.d.). Kemampuan Mahasiswa Dalam Menggunakan Media Pembelajaran.

Pinahayu, E. A. R., Auliya, R. N., Widya, L. P., \& Adnyani. (2018). Implementasi Aplikasi Wingeom untuk Pengembangan Bahan Ajar di SMP. Jurnal PKM: Pengabdian kepada Masyarakat, 01(02), 112-121.

Pramswari, L. P. (2016). Persepsi Guru SD terhadap Penelitian Tindakan Kelas, 3(1), 53-68. https://doi.org/10.17509/mimbar-sd.v3i1.2355.

Sidarta, K. T., \& Yunianta, T. N. H. (2019). Pengembangan Kartu Domano (Domino Matematika Trigono) sebagai Media Pembelajaran pada Matakuliah Trigonometri. Scholaria: Jurnal Pendidikan dan Kebudayaan, 9(1), 62-75. https://doi.org/10.24246/j.js.2019.v9.i1.p62-75.

Suratmi, S., Purwaningsih, S. S., Sartika, E., \& Suryani, A. (2018). DIFUSI, Volume 1, No.1, Januari 2018, (1).

Zetty Azizatun Ni'mah. (2017). Urgensi Penelitian Tindakan Kelas Bagi Peningkatan Profesionalitas Guru Antara Cita dan Fakta. Jurnal Administrasi Pendidikan Realita Volume 15, No. 2 Tahun 2017, 15(2), 1-11. https://doi.org/10.1016/j.det.2012.08.002. 